\title{
The Effect of Mannitol Addition on Hydration in Acute Kidney Injury Event After High Dose Cisplatin Chemotherapy: An Ambispective Cohort Study
}

Andhika Rachman ( $\nabla$ andhikarachman@gmail.com )

Universitas Indonesia

Syahidatul Wafa

Universitas Indonesia

Pringgodigdo Nugroho

Universitas Indonesia

Sukamto Koesnoe

Universitas Indonesia

\section{Research Article}

Keywords: High dose cisplatin, mannitol, acute kidney injury

Posted Date: June 30th, 2021

DOI: https://doi.org/10.21203/rs.3.rs-643773/v1

License: (a) (i) This work is licensed under a Creative Commons Attribution 4.0 International License.

Read Full License

Version of Record: A version of this preprint was published at BMC Cancer on April 12th, 2022. See the published version at https://doi.org/10.1186/s12885-022-09456-w. 


\section{Abstract}

Background: Saline hydration with addition of mannitol have commonly being strategy to avoid cisplatin induced acute kidney injury. While the initial reports demonstrated that mannitol diuresis decreased cisplatin induced renal injury, others have shown renal injury to be worsened.

Objective: To compare the risk of acute kidney injury in cancer patients receiving high dose cisplatin with addition and without addition of mannitol.

Method: This was an ambispective cohort study based on consecutive sampling at Cipto Mangunkusumo General Hospital and Mochtar Riady Comprehensive Cancer Centre (MRCCC) Siloam Hospitals. The data was obtained from September 2017 to February 2018. The choice of mannitol administration based on responsible physician clinical judgement. The outcome was any increment more than $0,3 \mathrm{mg} / \mathrm{dl}$ or 1,5 times from baseline of serum creatinine. Analysis was done by using SPSS statistic for univariate, bivariate and multivariate logistic regression to obtain crude risk ratio and adjusted risk ratio of cisplatin induced acute kidney injury probability of mannitol addition on hydration.

Result: Data from 110 patients (57,3\% male) with a median age of 44,5 years (range 19 to 60 years) were collected; 47 received saline alone and 63 received saline with addition of mannitol. Acute kidney injury were higher in mannitol vs non mannitol group. Bivariate analysis showed higher probability of post chemotherapy AKI in mannitol group (RR 2,168; 95\% $\mathrm{Cl} 0,839-5,6)$. On multivariate analysis the adjusted RR was $3,52(95 \% \mathrm{Cl} 1,11-11,162 ; \mathrm{p}$ value $=0,033)$ by controlling age.

Conclusion: The addition of mannitol on hydration had higher risk of AKI after high dose cisplatin chemotherapy.

\section{Introduction}

Cisplatin is a platinum-based chemotherapy agent that currently used as front-line therapy in the treatment of various solid organ cancers, including head and neck, lung, testis, ovary, breast, bladder cancer and sarcoma (1-7). The therapeutic effects of cisplatin are significantly improved by dose escalation. However, high dose therapy of cisplatin is limited by significant side effects, such as nephrotoxicity, neurotoxicity, ototoxicity and emetogenicity (8-10). In particular, renal toxicity occurs in $20 \%-40 \%$ of patients in a dose dependent manner, therefore limits the amount of drug that can be administered(11-13).

Cisplatin injures mitochondrial DNA, mostly at the third segment of proximal tubular cells, result in renal mitochondrial dysfunction. This injury led to a decline in adenosine triphosphate production. Reduced $\mathrm{Na}$ K-ATPase activity leads to altered intracellular-extracellular sodium gradient, which inhibit normal sodium reabsorption. The reduction in renal blood flow (RBF) and glomerular filtration rate (GFR) is due to increased renal vascular resistance, activated by tubuloglomerular feedback from increased sodium delivery to the macula densa in the early distal tubule. Additionally, cisplatin could directly induce 
necrosis and apoptosis of renal tubular cells, resulting an inflammation and oxidative stress that worsen the renal injury $(10,11,14,15)$. The decrease in the glomerular filtration rate causes an increase in serum creatinine within 6 to 7 days and tend to remain elevated for 3-4 weeks after cisplatin administration (16-19).

Although renal impairment is transient and reversible, $43 \%$ of patients with acute kidney injury went on to develop an irreversible renal failure (20). Nephrotoxicity was the main reason of discontinuation of chemotherapy and inferior survival of patients $(12,13,20-23)$. The main protective measures currently employed in clinical practice are based on avoiding the excessive exposure of kidneys, basically by hydration and diuresis, such as mannitol. Mannitol, since it was filtered by the kidneys but not reabsorbed, it remains in the renal tubules and causes an increase in the delivery of sodium to the distal tubules and a continued osmotic diuresis. This results in a "flushing" effect in the renal tubules thus reducing cisplatin contact time with tubular cells, preventing it from evolving into toxic compounds that damage the kidneys and increase the elimination of cisplatin in the urine (24-26). On the other hand, potential nephrotoxicity of mannitol raised clinician's concerns. When administered to patients with normal kidney function, mannitol may cause hypokalemia due to increased flow rates in the aldosteroneresponsive distal nephron which leads to increased potassium loss. In contrast, given to patients with preexisting kidney failure, mannitol is found to be retained in circulation and may cause extracellular fluid volume expansion, hyponatremia, metabolic acidosis, and hyperkalemia $(27,28)$. Moreover, mannitol may induce extensive isometric renal proximal tubular vacuolization and intense afferent arteriolar constriction resulting in acute kidney injury $(29,30)$.

Meta-analysis from Bo Yang et al in adult patients at increased risk of AKI revealed that intravascular administration of mannitol does not convey additional benefit beyond adequate hydration (31). The role of mannitol as prevention of cisplatin-associated AKI has been investigated in some trials, but the result was conflicting whether nephroprotective or nephrotoxic so no definite recommendation regarding the nephroprotective effect of mannitol has emerged.

The non-comparative study by Hayes (1977)(16) was the first to state the advantage of hydration plus mannitol to reduce the risk of cisplatin nephrotoxicity. Then, the prospective phase II trial by Al-Sarraf (1982) (32) supported the results of the Hayes study (incidence of nephrotoxicity in mannitol plus hydration was $15 \%$ vs. $30 \%$ in hydration alone), unfortunately this result was not statistically validated and in the next cycle of cisplatin chemotherapy, mannitol showed no nephroprotective effect. After AlSarraf, there are four studies, i.e. by Santoso, Leu, Morgan and McKibbin. The only randomized controlled trials, so far, held by Santoso (2003)(17), reported that combination of hydration and mannitol resulted in significant decreased of 24-h creatine clearance rate (in $\mathrm{ml} / \mathrm{min}$ ) after chemotherapy compared to normal saline group ( $31 \pm 2,7$ vs $5,4 \pm 5,1, p=0.02$ ) so the study was prematurely terminated due to the trend of worse outcomes with concomitant mannitol. Leu (2010) (33), supported the result of Santoso study, revealed that combination of hydration and mannitol resulted in higher incidence of nephrotoxicity ( $9 \%$ vs $2 \%, p=0.36$ ). Meanwhile, Morgan (2014) (34) reported that patients who did not receive mannitol had a higher risk of nephrotoxicity (OR 2,646; $95 \% \mathrm{Cl}=1,008-6,944 ; \mathrm{p}=0,048)$. McKibbin (2015) (35) ${ }^{33}$, 
supported the result of Morgan, reported that saline-mannitol combination resulted in lower nephrotoxicity $(\mathrm{OR} 0,16 ; 95 \% \mathrm{Cl} 0,04-0,65 ; \mathrm{p}=0,01)$. However, those three studies were retrospective, with the limitation of missing data analysis. Recent studied regarding the topic still had split conclusions. A study by Williams et al. (2016) (36) found elevation of serum creatinine is more common in patients without mannitol and therefore suggested that in Mannitol reduces nephrotoxicity in patients receiving $\geq$ $70 \mathrm{mg} / \mathrm{m}^{2}$ Cisplatin. In the other hand a retrospective study by Begin et al. (2020) (37) stated that Mannitol is better given for patients who receive $<75 \mathrm{mg} / \mathrm{m}^{2}$ in terms of nephroprotection and that there is no benefit of adding Mannitol when the dose of Cisplatin is $\geq 75 \mathrm{mg} / \mathrm{m}^{2}$. Meanwhile, a research by $\mathrm{El}$ Hamamsy in (2017) (38) reported that when compared to hydration and acetazolamide, hydration and mannitol exhibits more frequent cisplatin-induced acute kidney injuries. However, Hamroun (39) and Makimoto (40) stated that there's still no compelling evidence of significance in the use of mannitol in regards of reducing nephrotoxicity.

In our institution, the administration of mannitol was still debatable. Since there was no prevailing standard of prevention of cisplatin nephrotoxicity, the choice of mannitol administration was based on responsible physician clinical judgement. Therefore, we undertook this study to determine if there was any difference in the risk of acute kidney injury in solid organ cancer patients treated by high dose cisplatin ( $\left.\geq 75 \mathrm{mg} / \mathrm{m}^{2}\right)$, between patients receiving saline hydration alone compared to those receiving saline with addition of mannitol.

\section{Method}

\section{Patient Selection}

This was an ambispective study (combination of prospective and retrospective method) of solid organ cancer patients treated with high dose cisplatin $\left(\geq 75 \mathrm{mg} / \mathrm{m}^{2}\right)$ at the Cipto Mangunkusumo General Hospital (CMGH) and Mochtar Riady Comprehensive Cancer Centre (MRCCC) Siloam Hospitals, Jakarta, approved by institutional review board. Data were collected from September 2017 until February 2018. On the prospective method, we took samples of patients underwent high doses of cisplatin chemotherapy at the chemotherapy ward of CMGH since September 2017. On the retrospective method, the patient data were collected from the medical record of $\mathrm{CMGH}$ and MRCCC Siloam Hospitals. Patients were included if they were 18-60 years old, had a pathologically confirmed diagnosis of solid organ cancer, had an adequate baseline of glomerular filtration rate equal to or greater than $60 \mathrm{ml} / \mathrm{menit} / 1.73 \mathrm{~m}^{2}$, had a good performance status (Karnofsky score $\geq 80$ ), received high dose cisplatin chemotherapy. The exclusion criteria were as follows : receive other potentially nephrotoxic drugs such as furosemide, non-steroidal anti-inflammatory drugs (NSAIDs), aminoglycosides, amphotericin B and cephalosporins or another chemotherapy agent (permetrexed, ifosfamide, gemcitabine, bevacizumab, cetuximab), had comorbidity such as malignant / uncontrolled hypertension with diastolic blood pressure $\geq 100 \mathrm{mmHg}$, congestive heart failure, any structural abnormalities of kidney (obstruction of the urinary tract, kidney cyst or kidney 
and urinary tract stones) diagnosed by radiology examination, suffered from any acute infection and was a pregnant women.

\section{Treatment Schedule}

The subjects were allocated into two groups: the group receiving the addition of mannitol to hydration prior to cisplatin chemotherapy, and the group receiving no mannitol. The administration of mannitol was based on clinical judgement of responsible physician, no intervention from researcher. Patient demographic information include age, sex, type of cancer, history of diabetes and history of hypertension, treatment data include mannitol use, chemotherapy regimen, cisplatin dose, history of previous cisplatin chemotherapy and cumulative cisplatin dose before current therapy, number of cycles of chemotherapy and concomitant radiotherapy. All subjects received the same saline-based hydration with $1-2 \mathrm{~L}$ of $0,9 \%$ saline over 1-2 hours and achieved euvolemic status before chemotherapy. All doses of cisplatin were diluted in $500 \mathrm{ml}$ of $0,9 \%$ saline and infused over $2-3$ hour. Patients in the mannitol cohort received $20 \mathrm{~g}$ admixed in the $0,9 \% 100 \mathrm{ml}$ saline prehydration. All patients received antiemetic premedication such as dexamethasone, $\mathrm{a}_{2}$ receptor blocker and diphenhydramine.

\section{Assessment of Outcome}

The outcome of this study was any grade of acute kidney injury (AKI), was defined using the National Cancer Institute's Common Terminology Criteria for Adverse Events (CTCAE v 4.0) grading scale for chemotherapy (41). AKI was defined by an increase of more than $0,3 \mathrm{mg} / \mathrm{dl}$ or 1,5 times from baseline of serum creatinine which was measured within 28 days after cisplatin chemotherapy.

\section{Statistical analysis}

The collected data was processed using SPSS statistics program version 20.0. To evaluate the differences in the patient characteristics, the chi-square test was used. Bivariate analysis was performed to determine crude relative risk (RR) probability of post-chemotherapy AKI between mannitol group to non-mannitol group. Multivariate logistic regression models were created to assess the potential confounders and revealed adjusted RR. All analyzes used 5\% significance limits.

\section{Results}

\section{Patient characteristics}

A total of 110 patients were included, 63 patients received addition of mannitol and 47 patients did not. The patient characteristics were listed in Table 1. The median age was 44,5 years old with an almost equal proportion of male and female (57,3\% vs. $41,8 \%$ ). More than $60 \%$ of patients diagnosed with head and neck cancer and treated with combination of cisplatin and 5-fluorouracyl (44,5\%). Most of patient underwent first cycle of cisplatin chemotherapy, received cisplatin dosage of $100 \mathrm{mg} / \mathrm{m} 2(67,3 \%)$. Greater than $95 \%$ of patients had never previous cisplatin chemotherapy series, so that cumulative dose received before current chemotherapy was lower than $100 \mathrm{mg} / \mathrm{m}^{2}$. Regarding comorbidities, only a small 
proportion of subjects were diagnosed with Diabetes Mellitus (2.7\%) and hypertension (7.3\%). For concomitant radiotherapy, most subjects (83.5\%) were not given concomitant radiotherapy. All of patients were on good performance status before chemotherapy.

In this study, both groups received $>3000 \mathrm{ml}$ of hydration in 24 hours pre and post chemotherapy, with an adequate urine production for 6 hours post-chemotherapy of (mean value of 2,58 $\pm 1,01 \mathrm{ml} / \mathrm{kgBW}$ / hour). All subjects had good pre-chemotherapy renal function, i.e. median ureum $24 \mathrm{mg} / \mathrm{dl}$, creatinine 0,8 $\mathrm{mg} / \mathrm{dL}$ and glomerular filtration rate (CKD-EPI) was 103,85 ml / minute / $1.73 \mathrm{~m} 2$. No subjects had creatinine $>1,5 \mathrm{mg} / \mathrm{dL}$ pre-chemotherapy. All of subjects had a good median potassium value of 4,07 $\mathrm{mEq} / \mathrm{L}$ with similar results on both groups. The clinical characteristics were listed in Table 2. 
Patient Demographics and Characteristics

\begin{tabular}{|c|c|c|c|}
\hline & $\begin{array}{l}\text { Mannitol }(n= \\
63)\end{array}$ & $\begin{array}{l}\text { No Mannitol (n } \\
=47 \text { ) }\end{array}$ & $\begin{array}{l}\mathrm{P} \\
\text { value }\end{array}$ \\
\hline Male sex $(n=63 ; 57,3 \%)$ & $40(63,5)$ & $24(51,1)$ & 0,189 \\
\hline \multicolumn{4}{|l|}{ Age, median 44,5 yo } \\
\hline$\geq 40$ years old $(n=71 ; 64,5)$ & $32(51,6)$ & $39(81,2)$ & 0,001 \\
\hline \multicolumn{4}{|l|}{ Type of cancer } \\
\hline Nasopharynx $(n=61 ; 55,5 \%)$ & $41(66,1)$ & $20(41,7)$ & 0,001 \\
\hline $\begin{array}{l}\text { Head and neck cancer other than nasopharyngeal }(n= \\
14 ; 12,7 \%)\end{array}$ & $8(12,9)$ & $6(12,5)$ & \\
\hline Osteosarcoma ( $\mathrm{n}=11 ; 10 \%)$ & $8(12,9)$ & $3(6,2)$ & \\
\hline Breast $(\mathrm{n}=3 ; 2,7 \%)$ & $0(0)$ & $3(6,2)$ & \\
\hline Ovary $(n=4 ; 3,6 \%)$ & $0(0)$ & $4(8,5)$ & \\
\hline Others $(n=17 ; 15,5 \%)$ & $58,0)$ & $12(25,1)$ & \\
\hline \multicolumn{4}{|l|}{ Anticancer drugs } \\
\hline $5 F U(n=49 ; 44,5 \%)$ & $40(64,5)$ & $9(18,8)$ & 0,00 \\
\hline Docetaxel $(n=20 ; 18,2 \%)$ & $10(16,1)$ & $9(18,8)$ & \\
\hline Paclitaxel $(n=10 ; 9,1 \%)$ & $2(3,2)$ & $8(16,7)$ & \\
\hline Doxorubicin $(\mathrm{n}=9 ; 8,2)$ & $7(11,3)$ & $3(6,2)$ & \\
\hline Nimotuzumab $(n=7 ; 6,45)$ & $0(0)$ & $7(14,6)$ & \\
\hline Etoposide $(n=5 ; 4,5)$ & $1(1,6)$ & $4(8,3)$ & \\
\hline Others ( $n=10 ; 9 \%)$ & $2(3,2)$ & $8(16,7)$ & \\
\hline \multicolumn{4}{|l|}{ Dose of Cisplatin $\left(\mathrm{mg} / \mathrm{m}^{2}\right)$} \\
\hline $100(n=74 ; 67,3)$ & $53(84,1)$ & $21(44,7)$ & 0,00 \\
\hline $80(n=7 ; 6.4)$ & $2(3,2)$ & $5(10,6)$ & \\
\hline $75(n=29 ; 6,4)$ & $8(12,7)$ & $21(44,7)$ & \\
\hline \multicolumn{4}{|l|}{ Chemotherapy Cycle } \\
\hline 1st $(n=69[62,7])$ & $34(54,0)$ & $35(74,5)$ & 0,81 \\
\hline 2nd (n = $22[20])$ & $17(27,0)$ & $5(10,6)$ & \\
\hline $3 r d(n=3[14])$ & $8(12,7)$ & $6(12,8)$ & \\
\hline
\end{tabular}




\begin{tabular}{|llll|}
\hline & $\begin{array}{l}\text { Mannitol }(\mathrm{n}= \\
\text { 63) }\end{array}$ & $\begin{array}{l}\text { No Mannitol }(\mathrm{n} \\
\mathbf{=} 47)\end{array}$ & $\begin{array}{l}\text { P } \\
\text { value }\end{array}$ \\
\hline 4th $(\mathrm{n}=5[4,5])$ & $4(6,3)$ & $1(2,1)$ & \\
\hline Diabetes Mellitus $(\mathrm{n}=3[2.7])$ & $0(0)$ & $3(6,4)$ & 0,75 \\
\hline Hypertension $(\mathrm{n}=8[7.3])$ & $4(6,3)$ & $4(8,5)$ & 0,47 \\
\hline $\begin{array}{l}\text { Concomitant Radiotherapy } \\
\text { No }(\mathrm{n}=91[83,5])\end{array}$ & & \\
\hline
\end{tabular}

Table 2

Clinical Characteristics of Subjects

\begin{tabular}{|lllll|}
\hline & \multicolumn{2}{l}{ Before Chemotherpy } & \multicolumn{2}{l|}{ After Chemotherapy } \\
\cline { 2 - 5 } & Mannitol & No Mannitol & Mannitol & No Mannitol \\
\hline Ureum, median (min-max) & $22(4-68)$ & $24(10-47)$ & $28,5(8-76)$ & $27(13-81)$ \\
\hline $\begin{array}{l}\text { Creatinine, median \{min-max) } \\
\text { mg/dl }\end{array}$ & $0,8(0,3-1,2)$ & $0,8(0,29-$ & $1,0(0,4-2,2)$ & $0,9(0,41-$ \\
\hline$<1, \mathrm{n}(\%)$ & $55(88,7)$ & $43(89,6)$ & $37(59,7)$ & $35(72,9)$ \\
\hline $1,1-1,5 \mathrm{n}(\%)$ & $7(11,3)$ & $5(10,4)$ & $19(30,6)$ & $11(22,9)$ \\
\hline$>1,5 \mathrm{n}(\%)$ & 0 & 0 & $6(9,7)$ & $2(4,2)$ \\
\hline $\begin{array}{l}\text { GFR, median } \text { \{min-max) } \\
\text { ml/minute/1,73m } 2\end{array}$ & $106,5(62,7-$ & $102(60-$ & $90,11 \pm 28,67$ & $90,48 \pm 35,58$ \\
\hline$<60, \mathrm{n}(\%)$ & $169,8)$ & $253,4)$ & & \\
\hline $\mathbf{6 0 - 9 0 , n ( \% )}$ & 0 & 0 & $11(17,7)$ & $5(10,4)$ \\
\hline$>90, \mathrm{n}(\%)$ & $14(22,6)$ & $14(29,2)$ & $18(29)$ & $22(45,8)$ \\
\hline Kalium, median $\{$ min-max) & $48(77,4)$ & $34(70,8)$ & $33(53,2)$ & $21(43,8)$ \\
\hline $\begin{array}{l}\text { Pre-chemotherapy hydration, } \\
\text { mean } \pm \text { SB }\end{array}$ & $4,14(3,03-$ & $3,9(2,8-$ & $3,845(2,8-$ & $4,0(2,3-5,1)$ \\
\hline
\end{tabular}

\section{Incidence and outcome of AKI}

The incidence of AKI was observed in 14 patients (22.6\%) in mannitol group versus 5 patients $(10.4 \%)$ in no mannitol group ( $\mathrm{p}$ value $=0,076 ; \mathrm{RR} 2,168 ; 95 \% \mathrm{Cl} 0,839-5,6$ ). All of subjects developed an increase of serum creatinine and decrease of glomerular filtration rate after chemotherapy. The decrease of renal 
function was more noticeable in mannitol group than no mannitol group. The increase of serum creatinine was $29 \%$ in mannitol vs. $16,7 \%$ in no mannitol group. The increase of serum creatinine from less than $1,0 \mathrm{mg} / \mathrm{dL}$ to $1,1-1,5 \mathrm{mg} / \mathrm{dL}$ was found to be greater in the mannitol group than no mannitol group (30,6\% vs $22,9 \%$ ). In addition, the increase in creatinine to more than $1,5 \mathrm{mg} / \mathrm{dL}$ were found to be higher in the group receiving mannitol than without mannitol (9,7\% vs $4,2 \%)$. Similarly, a decrease in GFR from more than $90 \mathrm{ml} / \mathrm{min} / 1,73 \mathrm{~m}^{2}$ to less than $60 \mathrm{ml} / \mathrm{min} / 1,73 \mathrm{~m}^{2}$, was greater in the mannitol group than without mannitol (17,7\% vs. $10,4 \%)$. The pre-post chemotherapy comparison of renal function is detailed in Table 3 and shown in Graph 1 and 2.

Table 3

The mean decline of pre-and post-chemotherapy renal function in the mannitol and no mannitol groups

\begin{tabular}{|c|c|c|c|c|c|c|c|c|}
\hline & $\begin{array}{l}\text { Mean of } \\
\text { Creatinine } \\
\text { Increase }\end{array}$ & SD & $\begin{array}{l}\mathrm{P} \\
\text { Value }\end{array}$ & $95 \% \mathrm{Cl}$ & $\begin{array}{l}\text { Mean of } \\
\text { GFR } \\
\text { Decline }\end{array}$ & SD & $\begin{array}{l}\mathrm{P} \\
\text { value }\end{array}$ & $95 \% \mathrm{Cl}$ \\
\hline Mannitol & 0,218 & 0,291 & 0,00 & $\begin{array}{l}0,144- \\
0,291\end{array}$ & 16,532 & 21,12 & 0,00 & $\begin{array}{l}11,17- \\
21,89\end{array}$ \\
\hline $\begin{array}{l}\text { No } \\
\text { Mannitol }\end{array}$ & 0,154 & 0,244 & 0,00 & $\begin{array}{l}0,087 \\
-0,229\end{array}$ & 14,577 & 29,98 & 0,00 & $\begin{array}{l}5,87- \\
23,28\end{array}$ \\
\hline
\end{tabular}

\section{Potential risk factor for developing AKI}

We conducted bivariate analysis to analyze the potential confounding factor for such variables: age, sex, type of cancer, chemotherapy regimen, cisplatin dose, chemotherapy cycle, comorbidity of diabetes and hypertension and the administration of concomitant radiotherapy. The variables having $p$ values $<0,25$ in bivariate analysis were included in the multivariate analysis. The result of bivariate analysis was listed in Table 4. Based on bivariate analysis, the variables included in the multivariate analysis were age and chemotherapy regimen. Multivariate analysis and changes of crude RR (relative risk) to be adjusted RR between mannitol and post-chemotherapy AKI incidence by controlling the potential confounding factors were listed in Table 5. 
Table 4

The relationship between potential confounding factors and post-cisplatin acute kidney injury

\begin{tabular}{|c|c|c|c|}
\hline \multirow[t]{2}{*}{ Variables } & \multicolumn{2}{|c|}{$\begin{array}{l}\text { Post chemotherapy } \\
\text { AKI (\%) }\end{array}$} & \multirow[t]{2}{*}{ p } \\
\hline & Yes & No & \\
\hline \multicolumn{4}{|l|}{ Age } \\
\hline$<40$ years old & 10,3 & 89,7 & 0,149 \\
\hline$\geq 40$ years old & 21,1 & 78,9 & \\
\hline \multicolumn{4}{|l|}{ Sex } \\
\hline Male & 18,5 & 81,5 & 0,692 \\
\hline Female & 15,6 & 84,4 & \\
\hline \multicolumn{4}{|l|}{ Type of Cancer } \\
\hline Nasopharyngeal & 18,0 & 82,0 & 0,467 \\
\hline Head and neck other than & 7,1 & 92,9 & \\
\hline masopriaryngear & 9,1 & 90,9 & \\
\hline $\begin{array}{l}\text { Others } \\
\text { Otharcoma }\end{array}$ & 25 & 75 & \\
\hline \multicolumn{4}{|l|}{ Regimen of Chemotherapy } \\
\hline $5 F U$ & 26,5 & 73,5 & 0,146 \\
\hline Docetaxel & 10,5 & 89,5 & \\
\hline Paclitaxel & 10,0 & 90,0 & \\
\hline Doxorubicin & 0 & 100 & \\
\hline Others & 13,6 & 86,4 & \\
\hline \multicolumn{4}{|l|}{ Dose of Cisplatin $\left(\mathrm{mg} / \mathrm{m}^{2}\right)$} \\
\hline 100 & 10,3 & 89,7 & 0,525 \\
\hline 80 & 0 & 100 & \\
\hline 75 & 21,6 & 78,4 & \\
\hline
\end{tabular}




\begin{tabular}{|llll|}
\hline Variables & \multicolumn{2}{l}{$\begin{array}{l}\text { Post chemotherapy } \\
\text { AKI (\%) }\end{array}$} \\
\cline { 2 - 3 } & Yes & No & \\
\hline Cycle of Chemotherapy & & & \\
1 st & 16,2 & 83,8 & 1,00 \\
2 nd & 21,7 & 78,3 & \\
3 rd & 20,0 & 80,0 & \\
4 th & 0 & 100 & \\
Diabetes Mellitus & 0 & 100 & 1,00 \\
No DM & 17,8 & 82,2 & \\
Hypertension & 36,4 & 63,6 & 0,942 \\
No Hypertension & 15,2 & 84,8 & \\
Concomitant Radiotherapy & & & \\
Yes & 11,1 & 89,8 & 0,734 \\
No & 18,5 & 81,5 & \\
\hline
\end{tabular}

Table 5

Crude RR and Adjusted RR with $95 \% \mathrm{Cl}$ of mannitol on post-chemotherapy AKI with the addition of potential confounding factors gradually

\begin{tabular}{|llll|}
\hline Variables & RR (Cl 95\%) & $\begin{array}{l}\text { P value } \\
\text { verude } R R\end{array}$ & $\begin{array}{l}\text { RR value changes with } \\
\text { confounder }\end{array}$ \\
\hline Adjusted $R R$ & $2,168(0,839-5,6)$ & 0,094 & \\
\hline $\begin{array}{l}\text { + Chemotherapy regimen } 5 \\
\text { fluorouracyl }\end{array}$ & $\begin{array}{l}2,190(0,555- \\
8,632)\end{array}$ & 0,448 & $\begin{array}{l}(2,190-2,168) / 2,190 \times 100 \%= \\
1 \%\end{array}$ \\
\hline + Age $\geq 40$ years old & $\begin{array}{l}2,852(0,68- \\
11,96)\end{array}$ & 0,152 & $\begin{array}{l}(2,852-2,190) / 2,190 \times 100 \%= \\
23 \%\end{array}$ \\
\hline & & & \\
\hline
\end{tabular}

On multivariate analysis by controlling age and chemotherapy regimen, the risk of post cisplatin AKI was 3,5 times greater in saline with addition of mannitol than saline only (adjusted RR was 3,52; $95 \% \mathrm{Cl} 1,11-$ $11,162, \mathrm{p}$ value $=0,033$.

\section{Discussion}


Our data suggest that the addition of mannitol to saline hydration increased the risk of cisplatin-induced acute kidney injury (adjusted RR 2,446; 95\% Cl 0,614-9,741, p value =0,204). Age $\geq 40$ years old was concluded to be confounding factors.

The results of this study were consistent with the study from Santoso, et al (17) in the United States. This randomized controlled clinical trial found that decreased renal function, in this study assessed by 24 hours creatinine clearance, occurred more heavily in the group given the combination of hydration and mannitol than hydration alone $(31 \mathrm{ml} / \mathrm{min}$ vs $5,4 \mathrm{ml} / \mathrm{min}$, $\mathrm{p}$ value $=0,04)$. This study was discontinued prematurely because of higher tendency of nephrotoxicity in mannitol group, so that the expected sample size was not achieved (there were only 49 subjects). The discontinuation of study showed that nephrotoxicity potency of mannitol. However, the limitation of Santoso study was renal function parameters used, which was 24 hours creatinine clearance which required urine storage for 24 hours. Therefore, the potential of adherence-related bias in accommodating urine was a weakness of this study.

Our study also support the result of Leu et al (33), who reported the tendency of greater risk of nephrotoxicity in saline and mannitol group versus saline only (the decrease of creatinine clearance was $38,9 \mathrm{ml} / \mathrm{min}$ vs. 33,9 ml/min, $\mathrm{p}=0,09$ ) (33). However, Leu included the subjects treated with low dose cisplatin (40-75 mg/ $\left.\mathrm{m}^{2}\right)$, who were excluded in our study.

Our results differ from those of Hayes et al. (16), Morgan et al. (34), and McKibbin et al (35). However, the studies from Hayes (16) was non-comparative trial (no comparison data with patients receiving saline only), so it was difficult to analyze whether the nephroprotective outcome came from mannitol or adequate hydration only. Meanwhile, study from Morgan, reported the higher risk of nephrotoxicity from the group without mannitol (OR 2,646 (95\% Cl 1,008 - 6,944; $p=0.048)$ was a retrospective study and had small sample size (only 47 patients received high dose cisplatin). The study from McKibbin et al, (35) which support nephroprotective effect of mannitol after multivariate analysis (odds ratio of third grade nephrotoxicity in mannitol group was 0,$16 ; 95 \% \mathrm{Cl} 0,04-0,65$, p value $=0.01$ ) had a limitation in the analysis of concomitant use of nephrotoxic substance due to missing data because of the retrospective nature of study. Our study also differs from a more recent study by Begin et al. which included stated that there was no difference in AKI incidence between subject which was given mannitol in addition to hydration and hydration alone (HR 1.17 [0.75-1.82]) after administration of Cisplatin $\geq 75 \mathrm{mg} / \mathrm{m}^{2}$. The different hydration protocol in this study i.e., $3 \mathrm{~L}$ before and $1 \mathrm{~L}$ after Cisplatin compared to $1 \mathrm{~L}$ in our study, might be one of the reasons of this different outcome (37).

The underlying mechanisms of nephrotoxicity of mannitol was through the osmotic effect of mannitol which inhibits the reabsorption of water in the proximal tubule, resulted in urinary dilution and an increased diuresis. In one side, this effect decreased the contact time of cisplatin with renal tubular cells and increased the clearance of necrotic cell debris at renal tubules after injured by cisplatin. However, this mechanism seemed to have nephrotoxic potential, which was related with hemodynamic changes in the kidney. Mannitol triggered a marked decrease in the reabsorption of water and salt along the renal tubules, resulted in increased flow of water and salts from the proximal tubules, followed by increased 
sodium reabsorption in loop of Henle, distal tubules and collecting ducts. Increased excretion of urine solutes induced by the mannitol osmotic diuretic effect lead to increased tubuloglomerular feedback which stimulate afferent arteriolar vasoconstriction, hence resulted in decrease of glomerular filtration rate $(42,43)$. Besides that, mannitol would lead the osmotic nephrosis effect on renal tubules. Histologically, tubular cells with toxic effects of mannitol appeared to contain vacuoles resulting in edema, called osmotic nephrosis. Pathophysiologically, the mechanism was through the pinocytosis effect of mannitol into the proximal tubular cell at high osmolality which then causes tubular cell vacuolization. These vacuoles would become fused and develop an edematous cell, resulting an obstruction of renal tubules (44), then led to a decline in glomerular flow and acute kidney injury. Metaanalysis of Bo Yang et al. (31) in 626 subjects revealed that intravascular mannitol administration did not provide additional benefit than adequate hydration alone in patients at risk of AKI, however in contrastinduced nephropathy, the effect was even detrimental (31).

We controlled age as confounding variables. Decreased renal function as an increasing of age was associated with decreased plasma flow velocity in glomerular capillaries and glomerular capillary ultrafiltration coefficient. In addition, there were hemodynamic changes associated with structural changes such as decreased renal mass, increased sclerotic glomeruli and tubulointerstitial fibrosis (45). The Davies and Shock study of inulin clearance reported a glomerular filtration rate decrease of $8 \mathrm{ml} /$ $\mathrm{min} / 1.73 \mathrm{~m} 2$ in each year from the age of 40 years old (46). The increasing trend of incidence of AKI with age was consistent with previous research results from Prasaja et al, which reported that over 50 years of age have a higher risk of nephrotoxicity after four cycles of chemotherapy $(0 \mathrm{R} 3,433 ; 95 \% \mathrm{Cl}$ 1,363-8,645) (47). The study from Perazella et al (48), Caglar et al (22), and de Jongh et al (49), revealed same result, that advancing age was one of the factors that increased the risk of nephrotoxicity (48).

Our study supports the potential nephrotoxic effect of mannitol after cisplatin chemotherapy. Our study had a larger sample size than Santoso's study and stronger association between mannitol addition to saline and the incidence of post cisplatin acute kidney injury than Leu study. Our study only included subjects who received high doses of chemotherapy and excluded subjects who received nephrotoxic drugs simultaneously, two important things that became a limitation in previous studies. For the outcome of renal function, we used serum creatinine parameters, as recommended by the National Cancer Institute's Common Terminology Criteria for Adverse Events (CTCAE v 4.0) grading scale for chemotherapy to minimize bias due to other measures, such as using 24-hour clearance creatinine (41).

There are several other things to consider when evaluating these results. Most notably, because of cohort nature of this study, we did not randomize patients to receive or not receive mannitol, rather we submit a decision based on clinical judgement of responsible physician. Besides that, our study did not analyze fluid intake at home and excess fluid loss caused by vomiting as a side effect of cisplatin chemotherapy. However, all our subjects had the same approach of post chemotherapy nausea and vomiting; the medication for nausea and vomiting prophylaxis was given to all subjects. There is a need for future prospective study where fluid intake and water balance are strictly controlled to determine better the magnitude of risk from mannitol. 
We hope the results of our study might become a consideration regarding the policy of addition of mannitol to hydration in cisplatin chemotherapy. This might have an added benefit in the costeffectiveness of chemotherapy if administration of mannitol is no longer routinely given in high-dose cisplatin chemotherapy nowadays.

\section{Conclusion}

In our patients, the addition of mannitol to hydration increases the risk of post high dose cisplatin chemotherapy acute kidney injury as compared with hydration only. Age $\geq 40$ years old were confounding factor in our study.

\section{Abbreviations}

- AKI: acute kidney injury

- Cl: confidence interval

- CMGH: Dr. Cipto Mangunkusumo General Hospital

- CTCAE: Common Terminology Criteria for Adverse Events

- DM: Diabetes Mellitus

- 5FU: fluorouracil

- GFR: glomerular filtration rate

- HR: hazard ratio

- MRCCC: Mochtar Riady Comprehensive Cancer Center

- NSAID: Non-steroid anti inflammatory drugs

- OR: odds ratio

- RR: relative risk

\section{Declarations}

\section{Acknowledgements:}

none to declare

\section{Funding:}

none

\section{Availability of data and materials:}

not applicable 
Ethical approval for this study was granted by The Ethics Committee of The Faculty of Medicine, Universitas Indonesia. EA number: 815/UN2.F1/ETIK/2017

\section{Competing interests:}

The authors declare that they have no competing interests.

\section{Consent for publication:}

Yes.

\section{Authors' contributions:}

All the authors contributed equally

\section{References}

1. Blanchard EM. Cisplatin and solid tumors: Still working, after all these years. J Solid Tumors. 2012;2(1):26-33.

2. Schiller JH, Harrington D, Belani CP, Langer C, Sandler A, Krook J, et al. Comparison of Four Chemotherapy Regimens for Advanced Non-Small-Cell Lung Cancer. N Engl J Med. 2002;346(2):92-8.

3. Turrisi AT, Kim K, Blum R, Sause WT, Livingston RB, Komaki R, et al. Twice-Daily Compared with Once-Daily Thoracic Radiotherapy in Limited Small-Cell Lung Cancer Treated Concurrently with Cisplatin and Etoposide. N Engl J Med. 1999;340(4):265-71.

4. Grossman BH, Natale RB, Tangen CM, Speight VO, Vogelzang NJ, Trump DL, et al. Neoadjuvant Chemotherapy Plus Cystectomy Compared With Cystectomy Alone for Locally Advanced Bladder Cancer. N Engl J Med. 2003;349(9):859-66.

5. Bajorin DF, Sarosdy MF, Pfister DG, Mazumdar M, Motzer RJ, Scher HI, et al. Randomized trial of etoposide and cisplatin versus etoposide and carboplatin in patients with good-risk germ cell tumors: A multiinstitutional study. J Clin Oncol. 1993;11(4):598-606.

6. Adelstein DJ, Li Y, Adams GL, Wagner H, Kish JA, Ensley JF, et al. An intergroup phase III comparison of standard radiation therapy and two schedules of concurrent chemoradiotherapy in patients with unresectable squamous cell head and neck cancer. J Clin Oncol. 2003;21(1):92-8.

7. Silver DP, Richardson AL, Eklund AC, Wang ZC, Szallasi Z, Li Q, et al. Efficacy of neoadjuvant cisplatin in triple-negative breast cancer. J Clin Oncol. 2010;28(7):1145-53.

8. Hartmann JT, Lipp HP. Toxicity of platinum compounds. Expert Opin Pharmacother. 2003;4(6):889901.

9. Yao X, Panichpisal K, Kurtzman N, Nugent K. Cisplatin nephrotoxicity: A review. Am J Med Sci [Internet]. 2007;334(2):115-24. Available from: http://dx.doi.org/10.1097/MAJ.0b013e31812dfe1e 
10. Miller RP, Tadagavadi RK, Ramesh G, Reeves WB. Mechanisms of cisplatin nephrotoxicity. Toxins. 2010.

11. Dos Santos NAG, Rodrigues MAC, Martins NM, Dos Santos AC. Cisplatin-induced nephrotoxicity and targets of nephroprotection: An update. Arch Toxicol. 2012;86(8):1233-50.

12. Tezcan S, Izzettin FV, Sancar M, Yumuk PF, Turhal S. Nephrotoxicity Evaluation in Outpatients Treated with Cisplatin-Based Chemotherapy Using a Short Hydration Method. Pharmacol \&amp; Pharm. 2013;

13. Bhat ZY, Cadnapaphornchai P, Ginsburg K, Sivagnanam M, Chopra S, Treadway CK, et al. Understanding the risk factors and long-term consequences of cisplatin-associated acute kidney injury: An observational cohort study. PLoS One. 2015;

14. Hanigan MH, Devarajan P. Cisplatin nephrotoxicity: molecular mechanisms. Cancer Ther. 2003; (1):47-61.

15. Kubala M, Geleticova J, Huliciak M, Zatloukalova M, Vacek J, Sebela M. Na+/K+-ATPase inhibition by cisplatin and consequences for cisplatin nephrotoxicity. Biomed Pap. 2014;158(2):194-200.

16. Hayes DM, Cvitkovic E, Golbey RB, Scheiner E, Helson L, Krakoff IH. High dose Cis-platinum diammine dichloride. Amelioration of renal toxicity by mannitol diuresis. Cancer. 1977;

17. Santoso JT, Lucci JA, Coleman RL, Schafer I, Hannigan E V. Saline, mannitol, and furosemide hydration in acute cisplatin nephrotoxicity: A randomized trial. Cancer Chemother Pharmacol. 2003;52(1):13-8.

18. Cornelison TL, Reed E. Nephrotoxicity and hydration management for cisplatin, carboplatin, and ormaplatin. Vol. 50, Gynecologic Oncology. 1993. p. 147-58.

19. Taguchi T, Nazneen A, Abid MR, Razzaque MS. Cisplatin-associated nephrotoxicity and pathological events. Contrib Nephrol. 2005;148(li):107-21.

20. Kidera Y, Kawakami H, Sakiyama T, Okamoto K, Tanaka K, Takeda M, et al. Risk factors for cisplatininduced nephrotoxicity and potential of magnesium supplementation for renal protection. PLoS One. 2014;9(7).

21. Morgan KP, Buie LW, Savage SW. The Role of Mannitol as a Nephroprotectant in Patients Receiving Cisplatin Therapy. Ann Pharmacother. 2012;

22. Caglar K, Kinalp C, Arpaci F, Turan M, Saglam K, Ozturk B, et al. Cumulative prior dose of cisplatin as a cause of the nephrotoxicity of high-dose chemotherapy followed by autologous stem-cell transplantation. Nephrol Dial Transplant. 2002;17(11):1931-5.

23. Hoek J, Bloemendal KM, van der Velden LAA, van Diessen JNA, van Werkhoven E, Klop WMC, et al. Nephrotoxicity as a dose-limiting factor in a high-dose cisplatin-based chemoradiotherapy regimen for head and neck carcinomas. Cancers (Basel). 2016;8(2):1-9.

24. Muraki K, Koyama R, Honma Y, Yagishita S, Shukuya T, Ohashi R, et al. Hydration with magnesium and mannitol without furosemide prevents the nephrotoxicity induced by cisplatin and pemetrexed in patients with advanced non-small cell lung cancer. J Thorac Dis. 2012;4(6):562-8. 
25. Tsai SF, Shu KH. Mannitol-induced acute renal failure. Clin Nephrol. 2010;74(1):70-3.

26. Fang L, You H, Chen B, Xu Z, Gao L, Liu J, et al. Mannitol is an independent risk factor of acute kidney injury after cerebral trauma: A casecontrol study. Ren Fail. 2010;32(6):673-9.

27. Fanous AA, Tick RC, Gu EY, Fenstermaker RA. Life-Threatening Mannitol-Induced Hyperkalemia in Neurosurgical Patients. World Neurosurg [Internet]. 2016;91:672.e5-672.e9. Available from: http://dx.doi.org/10.1016/j.wneu.2016.04.021

28. Kim MY, Park JH, Kang NR, Jang HR, Lee JE, Huh W, et al. Increased risk of acute kidney injury associated with higher infusion rate of mannitol in patients with intracranial hemorrhage: Clinical article. J Neurosurg. 2014;120(6):1340-8.

29. Visweswaran P, Massin EK, Dubose TD. Mannitol-Induced Acute Renal Failure. J Am Soc Nephrol. 1997;8:1028-33.

30. Dickenmann M, Oettl T, Mihatsch MJ. Osmotic Nephrosis: Acute Kidney Injury With Accumulation of Proximal Tubular Lysosomes Due to Administration of Exogenous Solutes. Am J Kidney Dis. 2008;51(3):491-503.

31. Yang B, Xu J, Xu F, Zou Z, Ye C, Mei C, et al. Intravascular administration of mannitol for acute kidney injury prevention: A systematic review and meta-analysis. PLoS One. 2014;9(1):1-9.

32. Al-Sarraf M, LeBlanc M, Giri PGS, Fu KK, Cooper J, Vuong T, et al. Chemoradiotherapy versus radiotherapy in patients with advanced nasopharyngeal cancer: Phase III randomized Intergroup study 0099. J Clin Oncol. 1998;

33. Leu L, Baribeault D. A comparison of the rates of cisplatin (cDDP) - Induced nephrotoxicity associated with sodium loading or sodium loading with forced diuresis as a preventative measure. $J$ Oncol Pharm Pract. 2010;16(3):167-71.

34. Morgan KP, Snavely AC, Wind LS, Buie LW, Grilley-Olson J, Walko CM, et al. Rates of Renal Toxicity in Cancer Patients Receiving Cisplatin With and Without Mannitol. Ann Pharmacother. 2014;48(7):8639.

35. McKibbin T, Cheng LL, Kim S, Steuer CE, Owonikoko TK, Khuri FR, et al. Mannitol to prevent cisplatininduced nephrotoxicity in patients with squamous cell cancer of the head and neck (SCCHN) receiving concurrent therapy. Support Care Cancer [Internet]. 2016;24(4):1789-93. Available from: http://dx.doi.org/10.1007/s00520-015-2978-0

36. Williams RP, Ferlas BW, Morales PC, Kurtzweil AJ. Mannitol for the prevention of cisplatin-induced nephrotoxicity: A retrospective comparison of hydration plus mannitol versus hydration alone in inpatient and outpatient regimens at a large academic medical center. J Oncol Pharm Pract. 2016;23(6):422-8.

37. Bégin AM, Monfette ML, Boudrias-Dalle É, Lavallée E, Samouelian V, Soulières D, et al. Effect of mannitol on acute kidney injury induced by cisplatin. Support Care Cancer. 2020;29(4):2083-91.

38. El Hamamsy M, Kamal N, Bazan NS, El Haddad M. Evaluation of the effect of acetazolamide versus mannitol on cisplatin-induced nephrotoxicity, a pilot study. Int J Clin Pharm [Internet]. 2018;40(6):1539-47. Available from: https://doi.org/10.1007/s11096-018-0677-x 
39. Hamroun A, Lenain R, Bigna JJ, Speyer E, Bui L, Chamley P, et al. Prevention of Cisplatin-Induced Acute Kidney Injury: A Systematic Review and Meta-Analysis. Drugs [Internet]. 2019;79(14):1567-82. Available from: https://doi.org/10.1007/s40265-019-01182-1

40. Makimoto G, Hotta K, Oze I, Ninomiya K, Nakanishi M, Hara N, et al. Randomized study comparing mannitol with furosemide for the prevention of cisplatin-induced renal toxicity in non-small cell lung cancer: The OLCSG1406 trial. Asia Pac J Clin Oncol. 2021;17(1):101-8.

41. US Department of Health and Human Services. Common Terminology Criteria for Adverse Events (CTCAE) Version 4.0. National Cancer Institute. 2009.

42. Goldwasser $P$, Fotino $S$. Acute renal failure following massive mannitol infusion: appropriate response of tubuloglomerular feedback? Am J Nephrol. 1984;144(Nov):2214-6.

43. Lin SY, Tang SC, Tsai LK, Yeh SJ, Shen LJ, Wu FLL, et al. Incidence and risk factors for acute kidney injury following mannitol infusion in patients with acute stroke. Med (United States). 2015;94(47):e2032.

44. Nomani AZ, Nabi Z, Rashid H, Janjua J, Nomani H, Majeed A, et al. Osmotic nephrosis with mannitol: Review article. Ren Fail. 2014;36(7):1169-76.

45. Weinstein JR, Anderson S. The Aging Kidney: Physiological Changes. Adv Chronic Kidney Dis [Internet]. 2010;17(4):302-7. Available from: http://dx.doi.org/10.1053/j.ackd.2010.05.002

46. DAVIES DF, SHOCK NW. Age changes in glomerular filtration rate, effective renal plasma flow, and tubular excretory capacity in adult males. J Clin Invest. 1950;29(5):496-507.

47. Prasaja Y, Sutandyo N, Andrajati R. Incidence of cisplatin-induced nephrotoxicity and associated factors among cancer patients in Indonesia. Asian Pacific J Cancer Prev. 2015;

48. Perazella MA. Renal vulnerability to drug toxicity. Clin J Am Soc Nephrol. 2009;4(7):1275-83.

49. De Jongh FE, Van Veen RN, Veltman SJ, De Wit R, Van Der Burg MEL, Van Den Bent MJ, et al. Weekly high-dose cisplatin is a feasible treatment option: Analysis on prognostic factors for toxicity in 400 patients. Br J Cancer. 2003;88(8):1199-206.

\section{Figures}


The Comparison of Pre- and Post-Chemotherapy Glomerular Filtration Rate

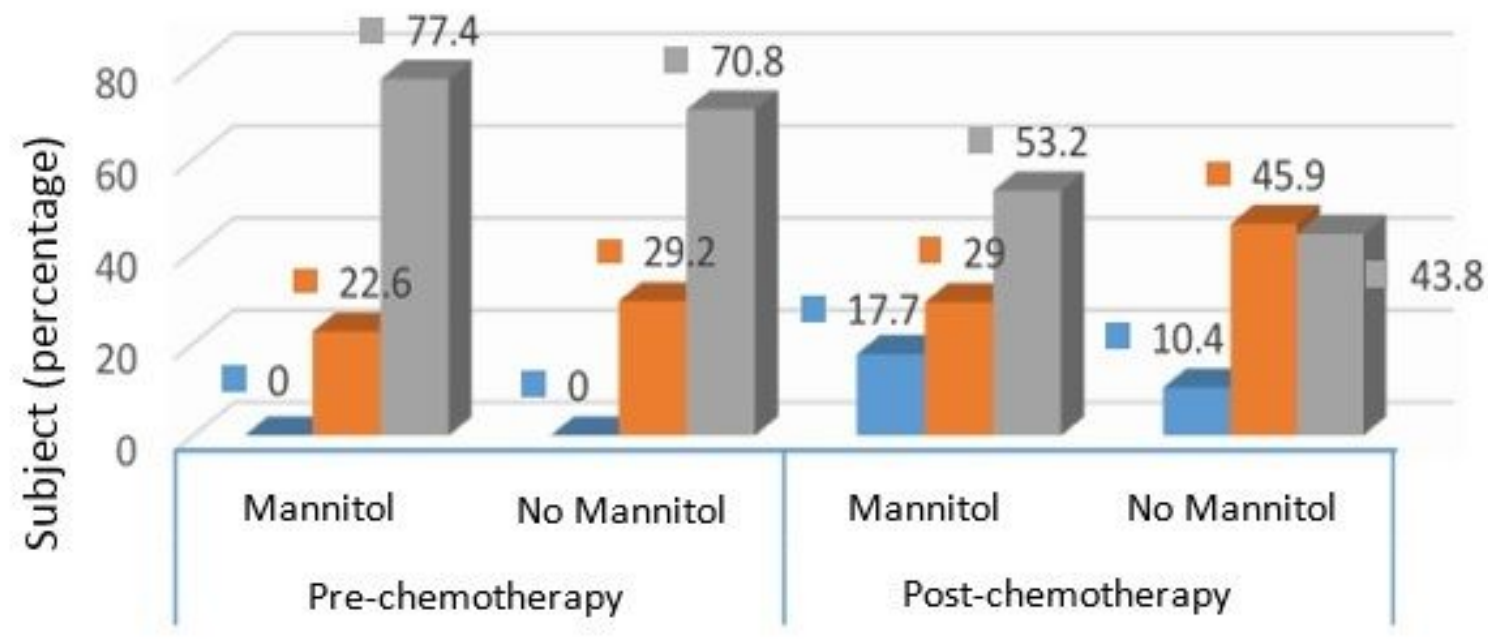

\section{Glomerular filtration rate}

$\quad<60 \quad$ a $60-90 \quad$ in $>90$

\section{Figure 1}

The comparison of glomerular filtration rate before and after chemotherapy 
The Comparison of Pre- and Post-Chemotherapy Creatinine

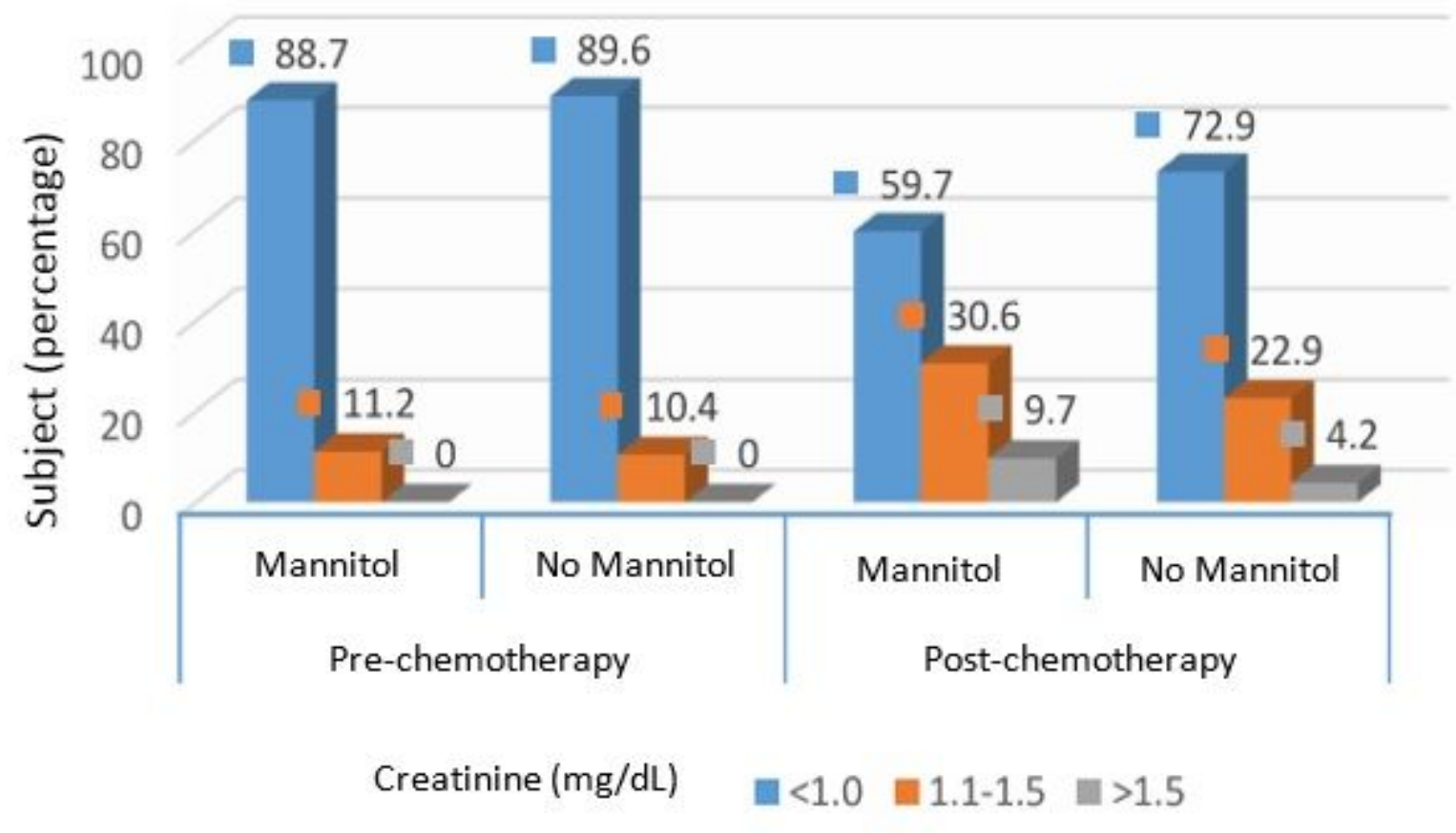

Figure 2

The comparison of serum creatinine before and after chemotherapy 